\title{
THE COMMITTEe ON ENFORCED DISAPPEARANCES AND ITS MONITORING PROCEDURES
}

\section{RICARDo A SUNGA III*}

\begin{abstract}
The International Convention for the Protection of All Persons from Enforced Disappearances establishes the Committee on Enforced Disappearances to oversee its implementation. Its reporting, individual communications and inter-state communications procedures have enhanced features that build on the experiences of other monitoring bodies with similar procedures. Its urgent visit and referral procedures contain novel elements that can promote compliance with the right not to be subjected to enforced disappearance. While issues of duplication, lack of enforcement powers, competence ratione temporis and time and resource constraints set the parameters of what it can and cannot do, the Committee, as part of a system of international and regional bodies, has the potential to induce respect for human rights and to help move states toward the goal of compliance with the right not to be subjected to enforced disappearance.
\end{abstract}

\section{INTRODUCTION}

This article explores the potential role of the Committee on Enforced Disappearances in promoting the objectives of the International Convention for the Protection of All Persons from Enforced Disappearance, ${ }^{1}$ and in fostering respect for the right not to be subjected to enforced disappearance

\footnotetext{
* Ricardo A Sunga III, LLB (University of the Philippines) and LLM by Research (University of New South Wales), is a lecturer at the College of Law of the University of the Philippines and former Director-Officer-in-Charge of the Institute of Human Rights of the University of the Philippines. He is also the Regional Coordinator for the National Capital region of the Free Legal Assistance Group of the Philippines. Thank you to Andrew Byrnes and Jane McAdam of the University of New South Wales for their guidance.

${ }^{1}$ International Convention for the Protection of All Persons from Enforced Disappearance 2006, GA Res 61/177, 20 December 2006, UN Doc A/RES/61/177 (2006), 14 IHRR 582 (2007), opened for signature 6 February 2007, entered into force 23 December 2010 ('Disappearances Convention').
} 
that the Convention explicitly guarantees. ${ }^{2}$ An independent body, ${ }^{3}$ the Committee is the principal organ established by the Convention to oversee its implementation. ${ }^{4}$

In accordance with the Convention, the Committee comprises 10 experts of high moral character and of recognised competence in the field of human rights. These Committee members serve in their personal capacity. ${ }^{5}$ Expected to be independent and impartial, members should 'neither seek nor accept instructions from anyone concerning the performance of their duties.

2 Ibid art 1 that states: '1. No one shall be subjected to enforced disappearance. 2. No exceptional circumstances whatsoever, whether a state of war or a threat of war, internal political instability or any other public emergency, may be invoked as a justification for enforced disappearance.' According to art 2: 'For the purposes of this Convention, "enforced disappearance" is considered to be the arrest, detention, abduction or any other form of deprivation of liberty by agents of the State or by persons or groups of persons acting with the authorization, support or acquiescence of the State, followed by a refusal to acknowledge the deprivation of liberty or by concealment of the fate or whereabouts of the disappeared person, which place such a person outside the protection of the law.'

3 The Working Group that drafted the Convention had debated whether to assign the monitoring functions to an existing body, the UN Human Rights Committee, or to establish a separate body (Commission on Human Rights, Civil and Political Rights, Including the Question of Enforced or Involuntary Disappearances: Report of the Intersessional Openended Working Group to Elaborate a Draft Legally Binding Normative Instrument for the Protection of All Persons from Enforced Disappearance, $59^{\text {th }}$ sess, UN Doc E/CN.4/2003/71 (12 February 2003) 6). As a compromise, the Committee's existence is subject to a later review at a conference of states parties. Article 27 of the Disappearances Convention states in this relation: 'A Conference of the States Parties will take place at the earliest four years and at the latest six years following the entry into force of this Convention to evaluate the functioning of the Committee and to decide, in accordance with the procedure described in article 44, paragraph 2, whether it is appropriate to transfer to another body - without excluding any possibility - the monitoring of this Convention, in accordance with the functions defined in articles 28 to 36 .'

${ }^{4}$ Ibid art 26; The first meeting of the states parties to the Disappearances Convention was held on 31 May 2011 at the United Nations Headquarters in New York. The meeting elected $\mathrm{Mr}$ Mohammed Al-Obaidi (Iraq), Mr Mamadou Badio Camara (Senegal), Mr Emmanuel Decaux (France), Mr Alvaro Garcé García y Santos (Uruguay), Mr Luciano Hazan (Argentina), Mr Rainer Huhle (Germany), Ms Suela Janina, (Albania), Mr Juan José López Ortega (Spain), Mr Enoch Mulembe (Zambia), and Mr Kimio Yakushiji (Japan), Office of the High Commissioner for Human Rights, Elections of the Members of the Committee on Enforced Disappearances (31 May 2011) <http://www.ohchr.org/EN/HRBodies/CED/Pages/ Elections2011.aspx>.

${ }^{5}$ Ibid art 26(1). For a critique of similar characteristics in the context of the Human Rights Committee, see Makau wa Mutua, 'Looking Past the Human Rights Committee: An Argument for De-Marginalizing Enforcement' (1998) 4 Buffalo Human Rights Law Review $211,222$. 
Members are accountable only to the Committee and their own conscience', ${ }^{6}$ and should

proceed in a victim-oriented and timely manner and maintain the highest standards of impartiality and integrity, and apply the standards of the Convention equally to all States and all individuals, independently, objectively, honourably, faithfully, conscientiously and without prejudice. ${ }^{7}$

In determining the Committee's composition, the Convention does not focus as much on the participation of stakeholders as the Convention on the Rights of Persons with Disabilities does. That convention goes as far as creating a duty to "closely consult with and actively involve persons with disabilities, including children with disabilities, through their representative organizations' in the nomination process and to consider the 'participation of experts with disabilities' in the election process. ${ }^{8}$ But the Disappearances Convention does promote the representation of a fair cross-section of the international community in the Committee's composition through its instruction to consider 'equitable geographical distribution' and 'balanced gender representation'. The states parties elect Committee members, taking due account of the usefulness of the participation in the work of the Committee of people having relevant legal experience. ${ }^{9}$

Part II of this article considers the extent to which the monitoring functions of this Committee can help strengthen the right not to be subjected to enforced disappearance. Part III takes stock of the different issues that the Committee faces in the exercise of its monitoring functions.

\section{Procedures}

Article 26 of the Disappearances Convention provides that the Committee's mandate is 'to carry out the functions provided for under this Convention'. The Committee's functions include engaging in: 1) a reporting procedure under article 29 of the Convention; 2) the urgent procedure under article 30 ;

\footnotetext{
${ }^{6}$ United Nations Committee on Enforced Disappearrances, Provisional Rules of Procedure of the Committee on Enforced Disappearances, UN Doc CED/C/1/R.1/Rev.1 (27 February 2012) Rule 10.

${ }^{7}$ Ibid.

${ }^{8}$ Anna Bruce, 'Negotiating the Monitoring Mechanisms for the Convention on the Rights of Persons with Disabilities' (2009), in Gudmundur Alfredsson et al (eds), International Human Rights Monitoring Mechanisms Essays in Honour of Jakob Th. Möller (Martinus Nijhoff, $2^{\text {nd }}$ ed, 2009) 133, 137.

${ }^{9}$ Disappearances Convention art 26(1).
} 
3) an individual communications procedure under article 31 ; 4) an inter-state communications procedure under article $32 ; 5$ ) a visit procedure under article 33 ; and 6) a referral procedure under article 34 . This Part critically examines each of the monitoring functions of the Committee in so far as they bear upon the ability of the Committee to promote the right not to be subjected to enforced disappearance.

\section{A Reporting Procedure}

Article 29 obliges each state party to submit to the Committee through the Secretary-General of the UN a report on the measures it has taken to give effect to its obligations under the Convention. It must do so within two years after the Convention's entry into force for the state party. The Committee will consider each report and will issue such comments, observations or recommendations as it deems appropriate. This procedure is a vital tool that enables the Committee to obtain information about and address a state party's record in the use of enforced disappearances. This reporting procedure in article 29 is the only mandatory monitoring mechanism of the Convention.

Like the reporting procedures of other treaty monitoring bodies, the Committee's reporting procedure will be based on a dialogue. ${ }^{10}$ Apart from the official government reports of the states parties, parallel reports by civil society groups and national human rights institutions on the situation in regard to enforced disappearances ${ }^{11}$ will be an important source of supplementary information for this dialogue. As Kjaerum asserts, these groups often possess knowledge about specific issues of which governments are not sufficiently aware or which they prefer to exclude from the official report. ${ }^{12}$

Parallel reports are especially useful devices in bringing to light hidden practices of enforced disappearance. These parallel reports can cover largely the same ground as the government reports, but can provide additional information from a much more critical perspective. When these reports are accurate, detailed and concise, they can have a major impact on the reporting process. ${ }^{13}$ Since it is in the interest of governments to present facts in the most

\footnotetext{
${ }^{10}$ Morten Kjaerum, 'State Reports' (2009), in Alfredsson, above n 8, 17, 22.

${ }^{11}$ They are also called shadow reports or alternative reports.

${ }^{12}$ Kjaerum, above n 10, 22.

${ }^{13}$ Henry J Steiner, Philip Alston and Ryan Goodman, International Human Rights in Context Law, Politics, Morals (Oxford University Press, $3^{\text {rd }}$ ed, 2007) 855.
} 
favourable light in their reports, other sources of information such as parallel reports are an essential aspect of informed monitoring. ${ }^{14}$

The reporting system does not relate to particular incidents, but rather the situation in general in regard to enforced disappearances. As Boerefijn observes in relation to the International Covenant on Civil and Political Rights (ICCPR), the procedure is not of a contentious nature, but aims at a constructive dialogue between states parties and the Committee. By means of a courteous, systematic and constructive exchange of views, concrete results can be achieved. ${ }^{15}$ In the context of the Convention against Torture, Bank points out that the system makes it possible for the Committee to make remarks pertaining to diverse aspects of treaty implementation, including positive aspects, factors and difficulties impeding the application of the Convention, issues of concern, and recommendations. ${ }^{16}$ In relation to the Disappearances Convention, this system enables the Committee to uncover patterns in the practice of enforced disappearance and to develop comprehensive approaches to address the problem.

Furthermore, the reporting procedure can serve as an important tool for clarifying normative issues and for interpreting and developing the right not to be subjected to enforced disappearance. The Committee can address normative issues through its 'Concluding Observations' comprising countryspecific comments that it can issue as part of its reporting procedure under article 29. These 'Concluding Observations', that is, specific comments on the situations in regard to enforced disappearances in the territories of states that have submitted reports, can be an important vehicle for clarifying the text of the Convention. As Buergenthal observes of the comparable reporting system under the ICCPR, the practice is to adopt Concluding Observations assessing

\footnotetext{
${ }^{14}$ Ineke Boerefijn, 'Towards a Strong System of Supervision: The Human Rights Committee's Role in Reforming the Reporting Procedure under Article 40 of the Covenant on Civil and Political Rights' (1995) 17 Human Rights Quarterly 766, 783-4, citing Francesco Capotorti, 'The International Measures of Implementation Included in the Covenants on Human Rights' in Asbjorn Eide and August Schou (eds), International Protection of Human Rights: Proceedings of the Seventh Nobel Symposium: Oslo 25-27 September 1967 (New York, Interscience; Stockholm, Almqvist and Wiksell, 1968) 132-48, 137.

${ }^{15}$ Ibid 772 .

${ }^{16}$ Roland Bank, 'International Efforts to Combat Torture and Inhuman Treatment: Have the New Mechanisms Improved Protection?' (1997) 8 European Journal of International Law 613,620 .
} 
the state's human rights situation and providing an insight into the manner in which the Committee interprets the ICCPR. ${ }^{17}$

Not only can the Committee issue Concluding Observations as part of the reporting procedure under article 29, but it can also issue a 'General Comment' that aims to clarify the text of the Disappearances Convention. Under its provisional Rules of Procedure, the Committee adopts a General Comment "with a view to promoting its implementation or to assisting States parties in fulfilling their obligations'. ${ }^{18}$ The power to issue General Comments can leave little room for 'loopholes and disingenuous interpretations'. ${ }^{19}$ General Comments of the UN Human Rights Committee today go well beyond even the literal text of the ICCPR. ${ }^{20}$ As Alston observes, the General Comment is 'one of the potentially most significant and influential tools available' to treaty bodies like the Committee. ${ }^{21}$

The reactions of states parties to the General Comments of the Committee on Enforced Disappearances may vary, as they have to the General Comments of other treaty bodies. Alston observes that some governments have claimed that certain General Comments are an unwarranted attempt to attribute to treaty provisions meanings that they do not have. ${ }^{22}$ Still, according to the International Law Association Committee on International Human Rights Law and Practice, courts have generally 'noted that while treaty bodies are not courts, their findings are relevant and useful in some contexts. However, courts have usually stopped short of concluding that they are obliged to follow treaty body interpretations, even in cases in which the treaty body has

\footnotetext{
17 Thomas Buergenthal, 'The Human Rights Committee' (2001) 5 Max Planck Yearbook of United Nations Law 341, 347 cited in Steiner, Alston and Goodman above n 14, 853.

${ }^{18}$ United Nations Committee on Enforced Disappearances, Provisional Rules of Procedure of the Committee on Enforced Disappearances, UN Doc CED/C/1/R.1/Rev.1 (27 February 2012) Rule 54(1).

19 Antonio Cassese, 'A New Approach to Human Rights: The European Convention for the Prevention of Torture' (1989) 83 American Journal of International Law 128, 129.

${ }^{20}$ Steiner, Alston and Goodman, above n 14, 884.

${ }^{21}$ Philip Alston, 'The Historical Origins of the Concept of 'General Comments' in Human Rights Law' (2001) in Laurence Boisson De Chazournes and Vera Gowlland-Debbas (eds), The International Legal System in Quest of Equity and Universality (Martinus Nijhoff, 2001) 763.

22 Ibid 764, citing I Boerefijn, The Reporting Procedure under the Covenant on Civil and Political Rights: Practice and Procedures of the Human Rights Committee (1999). Alston gives the example of the objection to the UN Human Rights Committee's General Comment 24 that relates to reservations.
} 
expressed a view on a specific case or law from the jurisdiction in question' ${ }^{23}$ Nevertheless, Steiner, Alston and Goodman add that UN bodies such as the Human Rights Council and the General Assembly, the International Court of Justice and regional human rights courts regularly invoke General Comments to interpret treaty provisions. ${ }^{24}$ Mechlem cites the "normative significance of General Comments for the development of human rights law'. ${ }^{25}$

General Comments can mean something similar for the Committee on Enforced Disappearances. They can be a comprehensive and coherent way of giving more concrete meaning to the text of the Disappearances Convention. Through analyses, elaboration and reasoned expounding of norms, these General Comments can serve as an important vehicle for making substantial arguments and for advancing interpretations of the Convention.

In addition, the Committee can build on the experience that other treaty monitoring bodies have with follow-up procedures. The Convention itself is silent on the matter of a procedure to follow up the comments, observations or recommendations that the Committee may issue. But, under the Committee's Provisional Rules of Procedure, if it appears that some of a state party's obligations under the Convention have not been discharged or that sufficient information has not been provided, the Committee may request this state party to provide the Committee with follow-up information to the Committee's concluding observations by a specified date. ${ }^{26}$ The Committee may also 'designate one or more Rapporteurs to follow up with the State party on its implementation of the concluding observations'. ${ }^{27}$ For its part, in accordance with rule 71(5) of its rules, the UN Human Rights Committee identifies

${ }^{23}$ International Law Association Committee on International Human Rights Law and Practice, 'Final Report on the Impact of Findings of the United Nations Human Rights Treaty Bodies' (Berlin Conference 2004) 3, citing Gómez Vásquez v Spain, Communication No 701/1996, UN Doc CCPR/C/69/D/701/1996 (16 August 2000); STC (Sentencia Tribunal Constitucional) (Spain) 70/2002, 3 April 2002, para 7; Kavanagh v Governor of Mountjoy Prison [2002] IESC 13 (1 March 2002) (Supreme Court of Ireland); Residents of Bon Vista Mansions $v$ Southern Metropolitan Local Council (2002) 6 BCLR 625 (High Court Witwatersrand, Local Division); and Minister for Immigration \& Multicultural \& Indigenous Affairs $v$ Al Masri [2003] FCAFC 70 [148]. See also International Law Association Committee on International Human Rights Law and Practice, 'Interim Report on the Relationship between General International Law and International Human Rights Law' (Toronto Conference 2006) 3.

${ }^{24}$ Steiner, Alston and Goodman, above n 14, 885.

25 Kerstin Mechlem, 'Treaty Bodies and the Interpretation of Human Rights' (2009) 42 Vanderbilt Journal of Transnational Law 905, 929.

${ }^{26}$ Provisional Rules of Procedure of the Committee on Enforced Disappearances, UN Doc CED/C/1/R.1/Rev.1 (27 February 2012), Rule 53(1).

${ }^{27}$ Ibid Rule 53(2). 
priority concerns in its Concluding Observations, on which a state party will submit follow-up information within one year, rather than in its next periodic report. In accordance with rule 72, the UN Human Rights Committee analyses this follow-up information through a special rapporteur appointed for the purpose. The Committee against Torture has a similar special rapporteur, while the Committee on the Elimination of Racial Discrimination has designated one of its members to follow up on its Concluding Observations. ${ }^{28}$

Beyond the initial report due within two years after the entry into force of the Convention, the Disappearances Convention does not mention any succeeding supplementary reports, unlike the Convention against Torture. ${ }^{29}$ But, in accordance with article 29(4), the Committee on Enforced Disappearances can request a state party to provide additional information on the implementation of the Convention. At the third and fourth drafting sessions, the delegates felt it important that the Committee be able to request this additional information. ${ }^{30}$

Still, there are concerns about the sustainability and duplication of the reporting systems of treaty monitoring bodies, including that of the Committee on Enforced Disappearances. As Steiner, Alston and Goodman point out, the reporting systems are fragmented, complex and underresourced, and the overlapping reporting burden and the uncoordinated responses of different committees are increasingly being challenged by governments. ${ }^{31}$ The authors cite a report commissioned by the UN General Assembly suggesting three long term options for reducing reporting burdens: i) reducing the number of treaty bodies and hence the number of reports required; ii) encouraging states to produce a single, global report to be submitted to all relevant treaty bodies; and iii) replacing the requirement of comprehensive periodic reports with specially tailored reports. ${ }^{32}$ Kjaerum emphasises that the treaty body system could have a greater impact on the development of human rights if some of the reporting obligations were

\footnotetext{
${ }^{28}$ Marcus Schmidt, 'Follow-Up Activities by UN Human Rights Treaty Bodies and Special Procedures Mechanisms of the Human Rights Council - Recent Developments' in Alfredsson, above n 8, 25, 29.

29 Convention against Torture and Other Cruel, Inhuman or Degrading Treatment or Punishment, opened for signature 10 December 1984, 1465 UNTS 85 (entered into force 26 June 1987) art 19 ('Convention against Torture').

${ }^{30}$ Commission on Human Rights, Report of the Intersessional Open-ended Working Group to elaborate a draft legally binding normative instrument for the protection of all persons from enforced disappearance, $61^{\text {th }}$ sess, UN Doc E/CN.4/2005/66 (10 March 2005) [30].

${ }^{31}$ Steiner, Alston and Goodman, above n 13, 921.

${ }^{32}$ Philip Alston, Final Report on Enhancing the Long-Term Effectiveness of the United Nations Treaty System, UN Doc E/CN.4/1997/74 (27 March 1996).
} 
harmonised and simplified. ${ }^{33} \mathrm{~A}$ group of former and current members of various treaty bodies have advocated that the different procedures of UN treaty bodies should be better coordinated, while each treaty body's autonomy and specific working methods should be respected. ${ }^{34}$ Such commentary is indicative of the ongoing reform process that aims at consolidation and unification. $^{35}$

The ongoing reform process does not diminish the importance of the Committee's reporting procedure as a monitoring tool. As Niemi and Scheinin point out, reporting makes a government accountable for its human rights policies before an international body. ${ }^{36}$ Still, the reporting procedure stands to be improved. ${ }^{37}$ As O'Flaherty points out, citing the 'Dublin Statement' made by 35 current and past members of treaty bodies, reform is a continuing process and not an isolated event. It ought to be the "normal state of the treaty body system, ${ }^{38}$

\section{B Individual Communications Procedure}

Article 31 enables the Committee to receive and consider communications from or on behalf of individuals subject to a state party's jurisdiction who claim to be victims of a violation by this state party of provisions of the Convention. The Committee will consider a communication inadmissible where:

\footnotetext{
${ }^{33}$ Kjaerum, above n 11, 23.

34 Poznan Statement on the Reforms of the UN Human Rights Treaty Body System (Poznan, Poland, 28-29 September 2010) [16].

${ }^{35}$ Michael Bowman, 'Towards a Unified Treaty Body for Monitoring Compliance with UN Human Rights Conventions? Legal Mechanisms for Treaty Reform' (2007) 7 Human Rights Law Review 225, 226.

${ }^{36}$ Heli Niemi and Martin Scheinin, Reform of the United Nations Human Rights Treaty Body System Seen from the Developing Country Perspective (June 2002) Institute for Human Rights, Åbo Akademi University, 68 < http://www.abo.fi/media/24259/report12.pdf>.

37 The limitations on the Committee's time and resources are discussed in section III of this article.

${ }^{38}$ Michael O'Flaherty, 'Reform of the UN Human Rights Treaty Body System: Locating the Dublin Statement' (2010) 10 Human Rights Law Review 319, 331 quoting Agnes Akosua Aidoo et al, The Dublin Statement on the Process of Strengthening of the United Nations Treaty Body System (19 November 2009) Office of the High Commissioner for Human Rights, [11]<http://www2.ohchr.org/english/bodies/HRTD/docs/DublinStatement.pdf $>$.
} 
(a) The communication is anonymous;

(b) The communication constitutes an abuse of the right of submission of such communications or is incompatible with the provisions of this Convention;

(c) The same matter is being examined under another procedure of international investigation or settlement of the same nature; or where

(d) All effective available domestic remedies have not been exhausted. This rule shall not apply where the application of the remedies is unreasonably prolonged. ${ }^{39}$

For the purpose of exhaustion of domestic remedies as a condition of admissibility, article $31(2)(d)$ requires exhaustion not of all domestic remedies, but of effective domestic remedies only. ${ }^{40}$

If the Committee considers that the communication is admissible, it will transmit the communication to the state party concerned, requesting that it provide observations and comments within a time limit set by the Committee. The Committee will hold closed meetings when examining communications. It will inform the author of a communication of the responses provided by the state party concerned. When the Committee decides to finalise the procedure, it will communicate its 'views' to the state party and to the author of the communication. In authorising the Committee to receive and consider communications 'from or on behalf of individuals,' article 31(1) leaves open the possibility of initiation by NGOs of communications. ${ }^{41}$

An individual communications procedure can promote the more effective implementation of the explicit guarantee, contained in the Convention, of the right not to be subjected to enforced disappearance and can enhance its enjoyment. To borrow the words of Byrnes and Connors, this procedure can 'provide redress for individual grievances, ... stimulate changes in discriminatory laws and practices, and ... create public awareness' of the right. ${ }^{42}$ The procedure in article 31 is based on the similar procedures of the

${ }^{39}$ Disappearances Convention art 31.

${ }^{40}$ Like article 25(5)(b) of the Convention against Torture, it builds on the experience under article 5(b) of the First Optional Protocol to the ICCPR.

${ }^{41}$ Commission on Human Rights, Report of the Intersessional Open-ended Working Group to Elaborate a Draft Legally Binding Normative Instrument for the Protection of All Persons from Enforced Disappearance, $62^{\text {nd }}$ sess, , UN Doc E/CN.4/2006/57 (2 February 2006) 13.

${ }^{42}$ Andrew Byrnes and Jane Connors, 'Enforcing the Human Rights of Women: A Complaints Procedure for the Women's Convention?' (1996) 21 Brooklyn Journal of International Law $679,699$. 
First Optional Protocol to the ICCPR, the Convention against Torture, the International Convention on the Protection of All Migrant Workers and Their Families and the Optional Protocol to the Convention on the Elimination of All Forms of Discrimination against Women, which have made important contributions to the implementation of human rights standards. ${ }^{43}$

But this individual communications procedure is only optional, in the sense that a state has the freedom to accept or reject it. By the terms of article 31 of the Convention, a state party needs to accept it by declaring at the time of ratification or at any time afterwards that it recognises the Committee's competence to receive and consider communications from or on behalf of individuals subject to that state's jurisdiction and claiming to be victims of a violation of provisions of the Convention by that state party. Sokhi takes the position that the voluntary nature of the individual communications procedure compromises it. Sohki's concern is that states can refuse the competence of the Committee by simply not accepting it. ${ }^{44}$ Although the optional character of the individual complaint system is one of the Protocol's weaknesses, it is unrealistic to expect states to make subjection to the complaint system mandatory upon themselves. It remains a question just how many states will accept the individual communications procedure in article $31 .{ }^{45}$

As with the reporting procedure, the Convention itself does not give any direction on follow-up of the Committee's views. But, under its Provisional Rules of Procedure, within six months of the Committee's transmittal of its 'views' on a communication, a concerned state party is obliged to submit to the Committee a written response, including information on any action taken in the light of the views and recommendations of the Committee. ${ }^{46}$ After the lapse of this period, the Committee may invite the state party concerned to submit further information about any measures which that state party has taken in response to its views or recommendations. 'The Committee shall designate a Rapporteur or Working Group for follow-up on Views to ascertain

\footnotetext{
${ }^{43}$ See also Optional Protocol to the International Covenant on Economic, Social and Cultural Rights opened for signature 24 September 2009 (not yet in force).

${ }^{44}$ Bal Sokhi-Bulley, 'The Optional Protocol to CEDAW: First Steps' (2006) 6 Human Rights Law Review 143, 157.

45 As of 24 April 2012, 12 of the 32 States parties have made a declaration recognising the competence of the Committee to receive individual communications under article 31.

${ }^{46}$ Provisional Rules of Procedure of the Committee on Enforced Disappearances, UN Doc CED/C/1/R.1/Rev.1 (27 February 2012) Rule 77(1).
} 
the measures taken by States parties to give effect to the Committee's Views and recommendations. ${ }^{47}$

The Committee has followed the lead of other treaty monitoring bodies in this regard. The UN Human Rights Committee has developed its own follow-up procedure upon the reasoning that it has the implied powers to do so. Accordingly, it has appointed a special rapporteur for follow-up on its views. As a matter of practice, it gives 90 days to a state party to provide information on measures taken to comply with the recommendations contained in its views. If the state party does not provide any, the special rapporteur may send a reminder, directly consult with state party representatives or organise a follow-up mission. The Committee against Torture, the Committee on the Elimination of Racial Discrimination and the Committee on the Elimination of Discrimination against Women have developed their own follow-up procedures that draw on the experience of the UN Human Rights Committee. $^{48}$

According to the case law that has arisen out of its individual communications procedure, the Committee can not only determine whether there has been a violation of the Convention, but it can clarify normative issues and strengthen the right not to be subjected to enforced disappearance. Though non-binding, the Committee's views have 'practical effects'. ${ }^{49}$ States often respond to these views and treat them as a serious matter. ${ }^{50}$ On the one hand, Nowak goes as far as calling treaty bodies like the UN Human Rights Committee 'quasijudicial' bodies, ${ }^{51}$ and Scheinin regards the so-called 'views' of the UN Human Rights Committee (which serve as its decisions on individual communications) as authoritative interpretations of the ICCPR. ${ }^{52}$ On the other hand, Steiner has argued that the UN Human Rights Committee cannot realistically serve the basic dispute resolution function that informs adjudication by courts in many national legal systems; it cannot effectively do justice in the individual case within the limits of its jurisdiction and to that

\footnotetext{
${ }^{47}$ Provisional Rules of Procedure of the Committee on Enforced Disappearances, UN Doc CED/C/1/R.1/Rev.1 (27 February 2012) Rule 77(4).

${ }^{48}$ Schmidt, above n 29, 25-7.

${ }^{49}$ Robert McCorquodale, 'The Individual and the International Legal System' in Malcolm D Evans (ed), International Law (Oxford University Press, $2^{\text {nd }}$ ed, 2006) 307, 318.

${ }^{50}$ Ibid 318 .

${ }^{51}$ Nowak and McArthur explain that all inquiries of the Committee against Torture so far have been based on information from NGOs. Manfred Nowak, Elizabeth McArthur and Kerstin Buchinger, The United Nations Convention against Torture (Oxford University Press, 2008) 581 referring to the Convention against Torture.

${ }^{52}$ Raija Hanski and Martin Scheinin (eds), Leading Cases of the Human Rights Committee (2003) 22, cited in Steiner, Alston and Goodman, above n 14, 915.
} 
extent vindicate the rule of law; and it cannot effectively protect rights under the ICCPR through deterrence. Steiner believes that ' $[\mathrm{w}]$ hat remains is the function of "expounding (elucidating, interpreting and explaining) the Covenant so as to engage the UN Human Rights Committee in an ongoing fruitful dialogue" with all relevant actors'. ${ }^{33}$

Despite the divergent opinions on the exact legal status of the views, their utility as vehicles for clarifying normative issues and for developing the various aspects of the right not to be subjected to enforced disappearance is difficult to dispute. As de Zayas observes in the context of the UN Human Rights Committee, though the Committee is not a judicial body, its interpretation of the ICCPR has yielded quotable jurisprudence. The development of follow-up procedures improves the implementation of its views and contributes to the perception that these views are meaningful expressions of human rights law. ${ }^{54}$

The Committee's individual communications procedure, through which it has the power to grant interim measures, can be a valuable tool to address urgent cases of enforced disappearance. At any time after the receipt of a communication and before a determination on the merits has been reached, the Committee can transmit to the state party concerned, for its urgent consideration, a request that the state party take such interim measures as may be necessary to avoid possible irreparable damage to the victims of the alleged violation. Where the Committee exercises its discretion, this does not imply a determination on admissibility or on the merits of the communication. ${ }^{55}$ The Convention thus makes express the practice of other treaty bodies in individual communications systems to grant interim measures.

The Committee on Enforced Disappearances can build on the experiences of other treaty bodies with interim measures. Though its Optional Protocol does not mention interim measures, the UN Human Rights Committee has issued them as a matter of practice in accordance with its rules. ${ }^{56}$ In $O E v S$, it had requested that an alleged victim who had sought refuge in a country not be expelled to another country pending consideration of the case. ${ }^{57}$ In Altesor $v$

\footnotetext{
${ }^{53}$ Steiner, Alston and Goodman, above n 14, 916.

${ }^{54}$ Alfred De Zayas, 'Petitions before the United Nations Treaty Bodies: Focus on the Human Rights Committee's Optional Protocol Procedure' in Alfredsson, above n 8, 35, 76.

${ }^{55}$ Disappearances Convention, art 31(4).

${ }^{56}$ See Rules of Procedure of the UN Human Rights Committee, UN Doc CCPR/C/3/Rev.10, 11 January 2012, Rule 92 < http://www.bayefsky.com/getfile.php/id/544/misc/rules>.

${ }^{57}$ OE v S, UN Human Rights Committee, Comm. No. 22/1977, UN Doc CCPR/C/OP/1, 26 July $1978,5$.
} 
Uruguay, it had requested information on the state of health of an alleged victim who had reportedly been beaten and subjected to electric shocks during detention. ${ }^{58}$ In Piandiong vs. Philippines, it had occasion to describe its own interim measures as essential to its role in its individual communications system. In that case, involving a request for a stay of the execution of three inmates on death row, the Committee stated that the mechanism should not be flouted by irreversible measures. ${ }^{59}$

The Committee on Enforced Disappearances may apply this provisional remedy of interim measures creatively in a variety of situations, as other international bodies have done. The Committee against Torture has similarly issued interim measures in accordance with its rules. ${ }^{60}$ In TPS $v$ Canada, acting on an applicant's allegation of a risk of torture in the event of deportation to India, the Committee against Torture had requested that the applicant not be deported pending examination of his communication. ${ }^{61}$ The African Commission on Human and Peoples' Rights has similarly issued interim measures. In International Pen, Constitutional Rights Project, Interights on behalf of Ken Saro-Wiwa Jr and Civil Liberties Organisation v Nigeria, the African Commission had adopted interim measures requesting a stay of the execution by the Nigerian military regime of a writer and activist Ken Saro-Wiwa Jr. ${ }^{62}$

As they have been for other treaty bodies, interim measures can be central to the protective function of the Committee on Enforced Disappearances. ${ }^{63}$ As Pasaluqui observes, the overriding importance of interim measures in human rights cases arises from their potential to terminate abuse. The consideration of communications can go on for months or even years. Interim measures can

58 Altesor v Uruguay, UN Human Rights Committee, Comm. No. 10/1977, UN Doc CCPR/C/15/D/10/1977, 29 March 1982 [2].

${ }^{59}$ Piandiong $v$ Philippines, UN Human Rights Committee, Comm. No 869/1999, 7 Selected Decisions 133 <http://www.ohchr.org/Documents/Publications/SDecisionsVol7en.pdf> cited in Steiner, Alston and Goodman above n 13, 896.

${ }^{60}$ See Committee against Torture, Rules of Procedure, UN Doc CAT/C/3/Rev.5 (21 February 2011), Rule 114.

${ }^{61}$ Committee against Torture, TPS v Canada, CAT/C/24/D/99/1997 (4 September 2000) $<$ http://www.unhcr.org/refworld/country,,CAT,,IND,,3f588ed03,0.html $>$.

${ }^{62}$ African Commission on Human and Peoples' Rights, Int'l Pen v. Nig, Comm. 137/94, 139/94, 154/96,161/97, 12th ACHPR AAR Annex V (1998-1999) $<$ http://www.worldcourts.com/achpr/eng/decisions/1998.10.31_Constitutional_Rights_Project _v_Nigeria.htm>, cited in Gino Naldo, 'International Measures in the UN Human Rights Committee' (2004) 53 International and Comparative Law Quarterly 445, 450.

63 Gino Naldo, 'International Measures in the UN Human Rights Committee' (2004) 53 International and Comparative Law Quarterly 445, 453. 
be instrumental in saving lives and avoiding irreparable injury. ${ }^{64}$ The interim measures that the Committee on Enforced Disappearances will be able to issue can help put an end to ongoing violations of the provisions of the Convention. Pending examination of individual communications that may take time to complete, the Committee can act swiftly by adopting the appropriate interim measures to avoid possible irreparable damage.

The individual communications procedure in article 31, with its feature of interim measures, is a classic procedure for human rights treaties and is a useful complement to the urgent procedure in article $30 .{ }^{65}$ Unlike the urgent procedure (that is confined to locating a disappeared person), the individual communications procedure covers breaches of the Convention relating to preventive and investigative measures. ${ }^{66}$

\section{Inter-State Communications Procedure}

In accordance with article 32, a state party can declare that it recognises the competence of the Committee to receive and consider communications in which a state party claims that another state party is not fulfilling its obligations under the Convention. There is no provision for interim measures in the inter-state communications system. The Committee will not receive communications concerning a state party that has not made such a declaration, nor communications from a state party that has not made such a declaration. ${ }^{67}$ 'The Committee may adopt a report concerning any communication received under article 32 of the Convention. ${ }^{68}$

States have yet to realise the importance of this inter-state communications procedure. This mechanism received little discussion during the drafting and was in fact suggested for inclusion only at the third and fourth drafting sessions of the Working Group. It is the weakest monitoring mechanism, ${ }^{69}$

${ }^{64}$ Jo M Pasqualucci, 'Interim Measures in International Human Rights: Evolution and Harmonization' (2005) 38 Vanderbilt Journal of Transnational Law 1, 4.

${ }^{65}$ Commission on Human Rights, Report of the Intersessional Open-ended Working Group to Elaborate a Draft Legally Binding Normative Instrument for the Protection of All Persons from Enforced Disappearance, 60 ${ }^{\text {th }}$ sess, UN Doc E/CN.4/2004/59 (23 February 2004) 27. The urgent procedure is discussed later in this section of the article.

${ }^{66}$ Ibid.

${ }^{67}$ As of 24 April 2012, 13 of the 32 states parties have made a declaration recognising the competence of the Committee to receive inter-state communications under article 32.

${ }^{68}$ Provisional Rules of Procedure of the Committee on Enforced Disappearances, UN Doc CED/C/1/R.1/Rev.1 (27 February 2012), Rule 85(1).

${ }^{69}$ Nowak and McArthur, above n 51, 701. 
because it does not seem likely to be used. Similar procedures in other human rights treaties have never been used. ${ }^{70}$

States parties to the Disappearances Convention are not likely to use this procedure. As Leckie points out, a possible reason for the lack of resort to the inter-state communications is the perceived political motivation for its use and its being potentially damaging and threatening to a state's interests. ${ }^{71}$ In Schwelb's words, it is not 'conducive to friendly relations between states'. ${ }^{72}$ For these reasons, those who drafted the Convention on the Rights of Persons with Disabilities did not see the importance of providing for such a monitoring mechanism.

Still, the inclusion of this mechanism in the Disappearances Convention adds to the range of available remedial options to address enforced disappearances. Leckie asserts certain procedural, legal and institutional benefits that can be derived from its use and argues that it remains a currently utilised mechanism, as evident from its use in other contexts. For example it has been used in a case between Tunisia and Libya within the monitoring system of the International Labour Organization and a case involving Turkey before the Council of Europe. ${ }^{73}$ However, other than these instances that Leckie cites from over 20 years ago, there is little indication of any added value to be gained from having the inter-state procedure.

\section{Urgent Procedure}

Article 30 enables the Committee to receive urgent requests that a disappeared person be sought and found. Relatives of the disappeared person, their legal representatives, their counsel, any person authorised by them or any other person having a legitimate interest, can submit the request. Article 30 empowers the Committee to request the state party concerned to provide information on the situation of the persons sought, within a time that the Committee sets, if the Committee considers that the request for urgent action:

\footnotetext{
${ }^{70}$ Ibid.

${ }^{71}$ Scott Leckie, 'The Inter-state Complaints Procedure in International Human Rights Law: Hopeful Prosepects or Wishful Thinking?' (1987-1988) 10 Human Rights Quarterly 249, 250.

${ }^{72}$ Egon Schwelb, 'The International Measures of Implementation of the International Covenant on Civil and Political Rights and of the Optional Protocol' (1977) 12 Texas International Law Journal 141, 161.

${ }^{73}$ Leckie, above n 71, 250.
} 
(a) Is not manifestly unfounded;

(b) Does not constitute an abuse of the right of submission of such requests;

(c) Has already been duly presented to the competent bodies of the State Party concerned, such as those authorised to undertake investigations, where such a possibility exists;

(d) Is not incompatible with the provisions of the Convention; and

(e) The same matter is not being examined under another procedure of international investigation or settlement of the same nature.

Based on the information that the state party concerned provides, the Committee can transmit recommendations to the state party. These recommendations can include a request that the state party take all the necessary measures, including interim measures, to locate and protect the person concerned in accordance with the Convention and to inform the Committee, within a specified period of time, of measures taken, taking into account the urgency of the situation. The Committee will then inform the person submitting the urgent action request of its recommendations and of the information that the state party concerned has provided to it. The Committee will continue its efforts to work with the state party concerned for as long as the fate of the person sought remains unresolved. The Committee will keep the person presenting the request informed. This urgent procedure is not subject to an explicit declaration by states parties that they accept the competence of the Committee, but they can 'opt out' by means of a specific reservation. ${ }^{74}$

The urgent procedure in article 30 enables the Committee to treat reported cases of enforced disappearance as an urgent matter and to address emergency situations. It takes into account that any delay in determining the disappeared person's fate can be crucial. It has the potential to resolve a number of issues relating to the right not to be subjected to enforced disappearance early on.

Though the urgent procedure has no precedent in a human rights treaty ${ }^{75}$ it is actually modeled on existing urgent action procedures. The Working Group

\footnotetext{
${ }^{74}$ Of the 32 states that have ratified the Convention as of 24 April 2012, none have opted out of the urgent procedure.

75 The Committee on the Elimination of Racial Discrimination does use an urgent procedure but it developed it through its rules. At its $71^{\text {st }}$ session in August 2007 the Committee adopted revised guidelines on its Early Warning and Urgent Action Procedure: Report of the Committee on the Elimination of Racial Discrimination, $71^{\text {st }}$ sess, A/62/18, Annexes, Chapter III.
} 
on Enforced or Involuntary Disappearances has a similar procedure in which its chairperson immediately communicates with a concerned government to seek information and cooperation in tracing a disappeared person. ${ }^{76}$ But the Working Group has derived its procedure not from any human rights treaty, but from its terms of reference laid down by the Commission on Human Rights, ${ }^{77}$ and now the Human Rights Council. These terms of reference include the mandate given to the members of the Working Group 'to perform their functions in an effective and expeditious manner'. ${ }^{78}$ Rodley has described the urgent procedure of the Working Group as perhaps its 'most important and radical technique'. ${ }^{79}$ The Working Group treats as urgent any information reliably suggesting that violations which come within its mandate by virtue of their gravity, are in danger of occurring or in the process of occurring. The evidence that the Working Group requires is of an arrest by public officials, with the detention remaining unacknowledged despite efforts to clarify the situation. ${ }^{80}$

The Committee similarly takes its cue from the experiences of other bodies that have resorted to urgent appeals, such as the Special Rapporteur on Torture, the Special Rapporteur on Religious Intolerance, the Working Group on Arbitrary Detention, the Special Rapporteur on Freedom of Expression, the Special Rapporteur on Racism, the Special Rapporteur on the Independence of Judges and Lawyers, the Special Rapporteur on Human Rights Defenders, the Special Rapporteur on Human Rights and Counter-Terrorism, the Special Rapporteur on the Right to Health and the Special Rapporteur on Violence against Women. ${ }^{81}$

The purpose of the Committee's own urgent procedure is to allow any person with a legitimate interest to request the monitoring body to seek and find a disappeared person. ${ }^{82}$ The urgent procedure assigns responsibility for taking

\footnotetext{
${ }^{76}$ Working Group on Enforced or Involuntary Disappearances, Report of the Working Group on Enforced or Involuntary Disappearances, UN Doc E/CN.4/1435 (1981), 8 and 16. I discuss further the establishment of this Working Group and its mandate in the next Part of this article.

${ }^{77}$ Commission on Human Rights, Resolution 20 (XXXVI), $1563^{\text {rd }}$ meeting on 29 February 1980, UN Doc E/CN.4/2004/59 (2004), Annex IV, 1.

${ }^{78}$ Ibid.

${ }^{79}$ Nigel Rodley, 'United Nations Action Procedures against "Disappearances", Summary or Arbitrary Executions, and Torture (1986) 8 Human Rights Quarterly 700, 711.

${ }^{80}$ Nigel Rodley, 'Urgent Action' in Alfredsson, above n 8, 191, 193.

${ }^{81}$ Ibid 191.

${ }^{82}$ Commission on Human Rights, Report of the Intersessional Open-ended Working Group to Elaborate a Draft Legally Binding Normative Instrument for the Protection of All Persons from Enforced Disappearance, 60 ${ }^{\text {th }}$ sess, UN Doc E/CN.4/2004/59 (23 February 2004) 26.
} 
preventive action to the Committee. Such a procedure seeks not only to forestall enforced disappearances, but also to put an end to those that have already occurred. ${ }^{83}$ The 'references to the notion of urgency ... indicate the configuration of the procedure more clearly'. ${ }^{84}$ Scovazzi and Citroni refer to the urgent procedure as an 'emergency procedure'. 85

The Committee enjoys a measure of discretion to 'assess situations on a caseby-case basis'. ${ }^{86}$ Article 30 makes possible a continuing dialogue between the Committee and the state party concerned until the fate of the disappeared person is clarified. The Committee will keep applicants informed of the replies received from the state party and the action taken in response to their applications. ${ }^{87}$ While this provision requires the notification of competent national authorities, the possibility remains for a state to respond to a complaint under its domestic law. ${ }^{88}$

The urgent procedure in article 30 is distinct from the individual communications procedure in article 31 . The objective of the urgent procedure is to 'seek, find and afford immediate protection to an individual', ${ }^{89}$ whereas the objective of the individual communications procedure is to determine a state's responsibility for a violation of the provisions of the Convention. ${ }^{90}$ In addition, while the individual communications procedure requires a separate declaration at the time of ratification by the state party that

\footnotetext{
${ }^{83}$ Commission on Human Rights, Report of the Intersessional Open-ended Working Group to Elaborate a Draft Legally Binding Normative Instrument for the Protection of All Persons from Enforced Disappearance, $61^{\text {th }}$ sess, UN Doc E/CN.4/2005/66 (10 March 2005) 31 [126].

${ }^{84}$ Commission on Human Rights, Report of the Intersessional Open-ended Working Group to Elaborate a Draft Legally Binding Normative Instrument for the Protection of All Persons from Enforced Disappearance, 62 ${ }^{\text {nd }}$ sess, UN Doc E/CN.4/2006/57 (2 February 2006) 11 [45].

${ }^{85}$ Tullio Scovazzi and Gabriella Citroni, The Struggle against Enforced Disappearance and the 2007 United Nations Convention (Martinus Nijhoff Publishers, 2007) 395.

${ }^{86}$ Commission on Human Rights, Report of the Intersessional Open-ended Working Group to Elaborate a Draft Legally Binding Normative Instrument for the Protection of All Persons from Enforced Disappearance, $61^{\mathrm{th}}$ sess, UN Doc E/CN.4/2005/66 (10 March 2005) 31.

${ }^{87}$ Ibid.

${ }^{88}$ Commission on Human Rights, Report of the Intersessional Open-ended Working Group to Elaborate a Draft Legally Binding Normative Instrument for the Protection of All Persons from Enforced Disappearance, $62^{\text {nd }}$ sess, UN Doc E/CN.4/2006/57 (2 February 2006) 11.

${ }^{89}$ Commission on Human Rights, Report of the intersessional open-ended working group to elaborate a draft legally binding normative instrument for the protection of all persons from enforced disappearance, $60^{\text {th }}$ sess, UN Doc E/CN.4/2004/59 (23 February 2004) 26 [153].

${ }^{90}$ Commission on Human Rights, Report of the Intersessional Open-ended Working Group to Elaborate a Draft Legally Binding Normative Instrument for the Protection of All Persons from Enforced Disappearance, 60 ${ }^{\text {th }}$ sess, UN Doc E/CN.4/2004/59 (23 February 2004) 26.
} 
it recognises the competence of the Committee to receive and consider individual communications, ${ }^{91}$ the urgent procedure has no similar requirement.

Furthermore, while the individual communications procedure is subject to the condition of exhaustion of 'all effective available domestic remedies', ${ }^{92}$ the urgent procedure only requires that the matter 'has already been duly presented to the competent bodies of the State Party concerned, such as those authorized to undertake investigations, where such a possibility exists' ${ }^{93}$ But both the urgent procedure and individual communications procedure are subject to the condition that the 'same matter is not being examined under another procedure of international investigation or settlement of the same nature'. ${ }^{94}$

The different nature of the urgent procedure explains the lesser conditions for its use. Its principal function is to respond immediately to a request that a disappeared person be sought and found. The imposition of a number of conditions would only slow down the urgent procedure in a way that is contrary to its nature and purpose. At the second session of the Working Group that drafted the Convention, many participants argued that the urgent procedure should not be contingent upon conditions such as the exhaustion of domestic remedies. ${ }^{95}$

The conditions to which the urgent procedure is subject ought to be kept to a minimum in order that it may operate expeditiously in keeping with its nature. But, in opposing the urgent procedure, the delegation of the Islamic Republic of Iran went in the other direction and proposed the inclusion of an additional admissibility criterion requiring the urgent action request to be corroborated by the facts. The Working Group appropriately did not accept the proposal since the necessary safeguards were already in place. ${ }^{96}$

\footnotetext{
${ }^{91}$ Disappearances Convention, art 31(1).

92 Ibid art 31(2)(d).

${ }^{93}$ Ibid art 30(2)(c).

${ }^{94}$ Ibid art 30(2)(e) and art 31(2)(c).

${ }^{95}$ Commission on Human Rights, Report of the intersessional open-ended working group to elaborate a draft legally binding normative instrument for the protection of all persons from enforced disappearance, $60^{\text {th }}$ sess, UN Doc E/CN.4/2004/59 (23 February 2004) 26 [153].

${ }^{96}$ Commission on Human Rights, Report of the Intersessional Open-ended Working Group to elaborate a draft legally binding normative instrument for the protection of all persons from enforced disappearance, $62^{\text {nd }}$ sess, UN Doc E/CN.4/2006/57 (2 February 2006) 11 [46].
} 
If there is any overlap among the provisions, it seems to be between the interim measures forming part of the urgent procedure in article 30 and the interim measures forming part of the individual communications procedure in article 31 . Through the urgent procedure in article 30 the Committee is able to accommodate requests made with a view not only to preventing the disappearance of a person, but also to taking interim protection measures. ${ }^{97}$ These interim measures under the urgent procedure are 'fundamental insofar as they involve the immediate adoption of specific measures to protect the rights of the persons concerned' ${ }^{98}$ Only a slight distinction can be drawn between the scope of these interim measures under the urgent procedure and those under the individual communications procedure. The latter seem broader in scope. Interim measures forming part of the individual communications procedure in article 31 aim 'to avoid possible irreparable damage', ${ }^{99}$ while interim measures forming part of the urgent procedure in article 30 aim more specifically to respond to a 'request that a disappeared person be sought and found'. ${ }^{100}$ Nonetheless, both kinds of interim measures can be useful in providing an immediate response to locate a disappeared person.

The urgent procedure in article 30 provides families with additional means to search for their disappeared relatives. As a remedy, it has potential to deliver immediate results to victims of enforced disappearance. Shelton states that ' $[\mathrm{t}]$ he remedial task is to convert law into results, to deter violations and restore the moral balance when wrongs are committed' ${ }^{101}$ An urgent procedure that may gain more visibility than other similar procedures on account of its being part of the mandate of a treaty body offers a greater possibility of being up to the task.

\section{E $\quad$ Visit Procedure}

Upon receipt of reliable information indicating a state party's serious violation of the provisions of the Convention, article 33 enables the Committee, after

\footnotetext{
${ }^{97}$ Commission on Human Rights, Report of the Intersessional Open-ended Working Group to elaborate a draft legally binding normative instrument for the protection of all persons from enforced disappearance, $60^{\text {th }}$ sess, UN Doc E/CN.4/2004/59 (23 February 2004) 26.

${ }^{98}$ Commission on Human Rights, Report of the Intersessional Open-ended Working Group to elaborate a draft legally binding normative instrument for the protection of all persons from enforced disappearance, $62^{\text {nd }}$ sess, UN Doc E/CN.4/2006/57 (2 February 2006) 11.

${ }^{99}$ Disappearances Convention, art 31(4).

${ }^{100}$ Ibid art 30(1).

${ }^{101}$ Dinah Shelton, Remedies in International Human Rights Law (Oxford University Press, 2nd ed, 2005) 20 .
} 
consultation with the state party concerned, to request one or more of its members to undertake a visit and report back to it without delay. ${ }^{102}$ The Committee must notify the state party concerned, in writing, of its intention to organise a visit, indicating the composition of the delegation and the purpose of the visit. The state party should answer the Committee within a reasonable time.

Upon receiving a substantiated request by the state party, the Committee can decide to postpone or cancel its visit. Should the state party agree to the visit, the Committee and the state party concerned must work together to define the modalities of the visit. The state party should provide the Committee with all the facilities needed for the successful completion of the visit. 'Visits may include hearings to enable the designated members of the Committee to determine facts or issues relevant to the assessments of the situation., ${ }^{103}$ Following its visit, the Committee must communicate to the state party concerned its observations and recommendations. This visit procedure is not subject to an explicit declaration by states parties that they will accept the competence of the Committee but they can 'opt out' by means of a specific reservation. ${ }^{104}$

The visit procedure in article 33 enables the Committee to respond to systematic violations of the rights that the Convention guarantees. This visit procedure is loosely based on the inquiry procedure in article 20 of the Convention against Torture and Other Cruel, Inhuman or Degrading Treatment or Punishment that may include a visit. ${ }^{105}$ Both procedures enable

${ }^{102}$ Article 33 does not state the purpose of the visit and apparently leaves it to the Committee to determine the purpose.

${ }^{103}$ Provisional Rules of Procedure of the Committee on Enforced Disappearances, UN Doc CED/C/1/R.1/Rev.1 (27 February 2012) Rule 93(1). See also Rule 97 on related protection measures, which provides: 'Where the Committee receives reliable information that a State party has been implicated in reprisals against individuals under its jurisdiction as a consequence of providing information or participating in any hearings or meetings in connection with a visit, it may request the State party concerned to adopt urgently measures to ensure protection of the concerned individuals and submit written explanations or clarifications thereon to the Committee.'

${ }^{104}$ Of the 32 states that have ratified the Convention as of 24 April 2012, none have opted out of the visit procedure.

${ }^{105}$ A similar inquiry procedure is provided for in Optional Protocol to the Convention on the Elimination of All Forms of Discrimination against Women, opened for signature 6 October 1999, 2131 UNTS 83 (entered into force 22 December 2000) arts 8 and 9; and in Optional Protocol to the Convention on the Rights of Persons with Disabilities, opened for signature 30 March 2007, GA Res A/Res/61/106 (entered into force 3 May 2008) arts 6 and 7. The Torture Convention itself draws on other models that include the International Labour Organization inquiry procedures and the UN Economic and Social Council Resolution 1503 (XLVIII) 
their respective Committees to receive reliable information from any source including NGOs. In relation to past experience with the inquiry procedure, Nowak and McArthur observe that the inquiry procedure 'resembles to some extent actio popularis by NGOs' on account of all inquiries of the Committee against Torture so far being based on information from NGOs. ${ }^{106}$ In relation to the inquiry procedure of the Committee on the Elimination of Discrimination against Women, Flinterman and Liu state that the inquiry procedure is an opportunity for NGOs to address the Committee on alleged systematic or grave violations of women's human rights. ${ }^{107}$ The visit procedure of the Committee on Enforced Disappearances will likely follow the same path.

What sets the two procedures in motion is substantially the same. For the visit procedure under the Disappearances Convention, it is 'reliable information indicating that a state party is seriously violating the provisions of this Convention' while for the inquiry procedure under the Convention against Torture, it is 'reliable information which appears to it to contain well-founded indications that torture is being systematically practised in the territory of a State Party'. In addition, the inquiry procedure involves inviting the cooperation of the state party concerned, while the visit procedure similarly involves consulting the state party concerned. What Flinterman and Liu have said about the inquiry procedure could just as well be said of the visit procedure: that it is not a complaint procedure; rather, the Committee has complete discretion to initiate the procedure after a determination of reliable information of gross or systematic violations, in the case of discrimination against women, or of serious violations, in the case of enforced disappearance. $^{108}$

But while the inquiry procedure is confidential, ${ }^{109}$ the visit procedure is not. Whereas article 20 of the Convention against Torture characterises the inquiry procedure as 'confidential', article 33 of the Disappearances Convention makes no such characterisation of the visit procedure and, in fact, makes it a duty of the Committee to communicate to the state party concerned its observations and recommendations at the end of a visit. The confidentiality of the inquiry procedure, which relies on 'close cooperation with the government

\footnotetext{
(1970) Procedure. See also the Optional Protocol to the International Covenant on Economic, Social and Cultural Rights that has yet to enter into force.

${ }^{106}$ Nowak and McArthur, above n 51, 65.

${ }^{107}$ Cees Flinterman and Ginney Liu, 'CEDAW and the Optional Protocol: First Experiences' (2009) in Alfredsson, above n 8, 91, 96.

108 Ibid.

${ }^{109}$ The deliberations, in particular, are confidential.
} 
concerned', ${ }^{110}$ leads to easier acceptance by states. Nevertheless, the inquiry procedure provides for the possibility of the inclusion of a summary account in the annual report of the Committee against Torture. ${ }^{111}$ Such a possibility 'constitutes the main tool of pressure on States parties that choose to ignore the provisions of the Convention against Torture and practice torture in a systematic and widespread manner, or prove to be uncooperative during the procedure'. ${ }^{112}$

The lack of confidentiality of the visit procedure poses a challenge to the Committee on Enforced Disappearances. It must devise ways to cooperate closely with states with which it needs to consult, ${ }^{113}$ to work together with them to define the modalities of a visit and to obtain the facilities needed for the successful completion of a visit. ${ }^{114}$ The fact that it may communicate its observations and recommendations without restriction ${ }^{115}$ can serve as an important incentive to the Committee on Enforced Disappearances to make the most of the visit procedure.

As a remedy for serious violations of provisions of the Convention, the visit procedure may well develop into an important fact-finding tool, like the inquiry procedure. ${ }^{116}$ In Vibhute's words, it is an innovative procedure for effectively preventing enforced disappearances. ${ }^{117}$ Furthermore, what Sokhi has said of the inquiry procedure - that it can contribute to a more detailed elaboration of the meaning of the obligations of states parties - can also be said of the visit procedure. ${ }^{118}$ Sørensen adds that the inquiry procedure is 'potentially forceful'. ${ }^{119}$ For her part, Mukherjee states that, although the inquiry procedure is time-consuming and relies on the responses of states and dialogue, it 'has developed into an advanced monitoring procedure' on

\footnotetext{
${ }^{110}$ Nowak and McArthur, above n 51, 662.

${ }^{111}$ Convention against Torture, art 20(5).

${ }^{112}$ Amrita Mukherjee, Torture and the United Nations, Charter and Treaty-Based Monitoring (Cameron May, 2008) 103.

${ }^{113}$ Disappearances Convention, art 33(1).

${ }^{114}$ Ibid art 33(4).

${ }^{115}$ Ibid art 33(5).

116 The inquiry procedure is also a key feature of the Optional Protocol to the International Covenant on Economic, Social and Culture Rights, opened for signature 24 September 2009, adopted 10 December 2008, GA Res A/RES/63/117 (not yet in force) art 11. See Claire Mahon, 'Progress at the Front: The Draft Optional Protocol to the International Covenant on Economic, Social and Cultural Rights' (2008) 8 Human Rights Law Review 617.

${ }^{117}$ Khushal Vibhute, 'The 2007 International Convention against Enforced Disappearance: Some Reflections' (2008) 2 Mizan Law Review 287, 309.

${ }^{118}$ Sokhi-Bulley, above n 45, 157.

${ }^{119}$ Bent Sørensen, 'CAT and Articles 20 and 22' (2009) in Alfredsson, above n 8, 99, 100.
} 
account of its fact-finding methodology that has produced detailed accounts. ${ }^{120}$

\section{F Referral Procedure}

Article 34 of the Convention provides for a procedure of urgent referral of a matter to the UN General Assembly through the Secretary-General. Upon the discovery of well-founded indications that enforced disappearance is being practised on a widespread or systematic basis in the territory under the jurisdiction of a state party, article 34 enables the Committee to bring the matter urgently to the attention of the General Assembly through the Secretary-General. ${ }^{121}$ Before doing so, the Committee must first seek all the relevant information on the situation from the state party concerned. ${ }^{122}$

Article 34 contemplates a referral to the political bodies of the UN, for which some other human rights treaties similarly provide. ${ }^{123}$ At the third and fourth sessions of the Working Group that drafted the Convention, the chairperson expressed his view that the referral enabled the Secretary-General to take the appropriate action in cases of a widespread and systematic practice of enforced disappearance. ${ }^{124}$ As some delegations observed during the third and fourth drafting sessions, the possible consequence of such a referral is the transmittal by the Secretary-General of the information to the Security Council. The Security Council could then bring a case before the International Criminal Court. ${ }^{125}$

The referral procedure in article 34 takes into account the urgency and gravity of the matter of enforced disappearances. At the fifth drafting session of the

\footnotetext{
${ }^{120}$ Mukherjee, above n 112, 103.

${ }^{121}$ Disappearances Convention art 34.

122 Ibid.

123 Other human rights instruments already allow matters to be brought before the political bodies of the UN, in particular, Convention on the Prevention and Punishment of the Crime of Genocide, opened for signature 9 December 1948, 78 UNTS 277 (entered into force 12 January 1951) art VIII ('Genocide Convention'); International Convention on the Suppression and Punishment of the Crime of Apartheid, opened for signature 30 November 1973, 1015 UNTS 243 (entered into force 18 July 1976) art VIII ('Apartheid Convention'); Commission on Human Rights, Report of the Intersessional Open-ended Working Group to Elaborate a Draft Legally Binding Normative Instrument for the Protection of All Persons from Enforced Disappearance, $61^{\text {th }}$ sess, UN Doc E/CN.4/2005/66 (10 March 2005) 33.

${ }^{124}$ Commission on Human Rights, Report of the Intersessional Open-ended Working Group to Elaborate a Draft Legally Binding Normative Instrument for the Protection of All Persons from Enforced Disappearance, $61^{\text {th }}$ sess, UN Doc E/CN.4/2005/66 (10 March 2005) 33. 125 Ibid.
} 
Working Group, several delegations observed that the referral procedure was important in light of the gravity of the crimes in question and drew attention to similar procedures under the Genocide Convention and the Apartheid Convention. ${ }^{126}$ Article 8 of the Genocide Convention enables any contracting party to "call upon the competent organs of the United Nations to take such action under the Charter of the United Nations as they consider appropriate for the prevention and suppression of acts of genocide', while article 8 of the Apartheid Convention allows any state party to 'call upon any competent organ of the United Nations to take such action under the Charter of the United Nations as it considers appropriate for the prevention and suppression of the crime of apartheid'. The comparable referral procedure in article 34 of the Disappearances Convention represents an acknowledgement of the serious character of the enforced disappearance that is not unlike that of genocide or apartheid.

Article 34 seeks to generate more comprehensive and coherent action within the UN system on the widespread and systematic practice of enforced disappearances. Article 34 paves the way for a referral of the urgent matter of disappearances to the UN General Assembly through the Secretary-General. The Convention thus establishes a link between the inquiry procedure and the visit procedure and establishes the possibility of ensuring that conclusions are followed up through the Secretary-General. ${ }^{127}$

In sum, the Disappearances Convention equips the Committee with a wide array of monitoring procedures. On the one hand, the rather large number of procedures risks causing confusion through duplication, as with the overlapping interim measures under the urgent procedure in article 30 and the individual communications procedure in article $31 .{ }^{128}$ On the other hand, the inclusion of practically every possible procedure helps ensure that the Committee has a range of options at its disposal to address different kinds of issues. For clarifying normative issues, the reporting procedure that is mandatory for all states parties to the Convention is a particularly potent tool for the Committee. By issuing General Comments or Concluding Observations as part of its reporting procedure, the Committee can develop the right of a person not to be subjected to enforced disappearance. Through

${ }^{126}$ Commission on Human Rights, Report of the Intersessional Open-ended Working Group to Elaborate a Draft Legally Binding Normative Instrument for the Protection of All Persons from Enforced Disappearance, $62^{\text {nd }}$ sess, UN Doc E/CN.4/2006/57 (2006) 14.

${ }^{127}$ Commission on Human Rights, Report of the Intersessional Open-ended Working Group to Elaborate a Draft Legally Binding Normative Instrument for the Protection of All Persons from Enforced Disappearance, $61^{\text {th }}$ sess, UN Doc E/CN.4/2005/66 (10 March 2005) 33.

${ }^{128}$ The next section of this article explores the issue of duplication further. 
declaring its views in its individual communications procedure (a procedure that requires a separate declaration on the part of states parties) the Committee can build jurisprudence that further clarifies normative issues.

Furthermore, the urgent procedure, individual communications procedure and inter-state communications procedure offer various forms of protection in urgent cases. The urgent procedure is the principal mechanism in emergency situations involving requests that a disappeared person be sought and found. Interim measures in the individual communications procedure can provide complementary protection in urgent cases. The inter-state communications procedure may prove useful in cases of a violation committed by a state party against another state party.

Finally, the visit procedure and referral procedure provide important remedial options in cases of systematic violations. The visit procedure is a fact-finding tool that makes possible visits by members of the Committee to places where serious violations of the provisions of the Convention are taking place. The referral procedure creates an avenue through which well-founded indications of the practice of enforced disappearance on a widespread or systematic basis can reach the attention of the UN General Assembly through the SecretaryGeneral.

\section{LIMITATIONS}

It is important to take stock of the limitations imposed on the Committee on Enforced Disappearances in order to understand and evaluate its role and character. This assessment of the Committee's potential relies heavily on the experience of other international bodies with similar procedures. As with these other international bodies, there are constraints on what the Committee can do.

\section{A Lack of Enforcement Powers}

The Committee on Enforced Disappearances, like other international treaty monitoring bodies, has no enforcement powers. After all, unlike commercial obligations, human rights obligations are generally non-reciprocal. As Cassese explains, states are not induced to comply with human rights obligations for fear that other states might otherwise feel at liberty to disregard them. ${ }^{129}$ Even when the right to initiate ex post facto adjudication is given to individuals and

${ }^{129}$ Cassese, above n 19, 151. 
international bodies and not just states, human rights obligations are not expected to compel compliance to the same extent as more reciprocal obligations, where the inherent incentives to comply are stronger. The prospect of an adverse human rights judgment does not cause as much fear to states as the retaliatory threat of economic disadvantage resulting from a breach of a commercial treaty. ${ }^{130}$ Such a limitation has led to calls for reform, including a call for a world court of human rights - an international human rights body able to establish the facts, decide on alleged violations and, in case of violations, provide adequate reparation. ${ }^{131}$ Since I am drawn to the ideal of an international human rights body with enforcement powers, I see hope and promise in the call for the establishment of a world court of human rights.

However, in the meantime, mindful of the non-binding character of the decisions of treaty monitoring bodies such as the Committee on Enforced Disappearances, I suggest that the improvement in their follow-up procedures is a significant and encouraging development. Schmidt describes follow-up activities as now being at the core of the activities of treaty monitoring bodies. He observes a growing realisation that effective follow-up activities provide the crucial basis for better and more consistent implementation at the domestic level by these bodies. This development of follow-up activities translates to a window of opportunity for the Committee on Enforced Disappearances. With physical compulsion outside of its competence, the challenge is greater for the Committee to build on the experience of other treaty monitoring bodies with follow-up procedures and to make creative use of its mandate to induce respect for the right not to be subjected to enforced disappearance. ${ }^{132}$

\section{B Duplication}

It may possibly be alleged that duplication occurs in the work of the Committee on Enforced Disappearances both at the international and regional levels. It seems that much of what the Committee is mandated to do is already being done by other bodies. This issue is particularly pronounced given the large number of procedures that the Committee has access to in monitoring the implementation of the Convention.

\footnotetext{
${ }^{130}$ Ibid.

${ }^{131}$ Manfred Nowak, 'Eight Reasons Why We Need a World Court of Human Rights' (2009), in Alfredsson, above n 8, 697.

${ }^{132}$ Schmidt, above n 29, 29.
} 


\section{$1 \quad$ International Treaty Bodies}

Several of the Committee's procedures are already being performed by other international treaty monitoring bodies. These other treaty bodies include the UN Human Rights Committee and the Committee against Torture. ${ }^{133}$ Both these treaty bodies have a reporting procedure, individual communications procedure and inter-state communications procedure like those provided for use by the Committee on Enforced Disappearances. ${ }^{134}$ Furthermore, the Committee against Torture has an inquiry procedure that is similar to the visit procedure of the Committee on Enforced Disappearances. ${ }^{135}$ However, as Sørensen observes, the inquiry procedure of the Committee against Torture concerns only torture, ${ }^{136}$ and does not concern 'other forms of cruel, inhuman or degrading treatment or punishment', nor other forms of organised violence such as enforced disappearances. ${ }^{137}$

The Committee against Torture has found enforced disappearance to be a violation of the Convention against Torture. It has stated in its Conclusions and Recommendations on the United States:

The State party should adopt all necessary measures to prohibit and prevent enforced disappearance in any territory under its jurisdiction, and prosecute and punish perpetrators, as this practice constitutes, per se, a violation of the Convention.

\footnotetext{
${ }^{133}$ The others are the Committee on Economic, Social and Cultural Rights, Committee on the Elimination of All Forms of Racial Discrimination, Committee on the Elimination of All Forms of Discrimination against Women, Committee on the Rights of the Child, Committee on Migrant Workers and Committee on Persons with Disabilities.

${ }^{134}$ ICCPR, arts 28, 40 and 41; First Optional Protocol to the ICCPR; and Convention against Torture, arts 17, 19, 21 and 22.

${ }^{135}$ Convention against Torture art 20.

${ }^{136}$ According to the Convention against Torture art 1, torture is: any act by which severe pain or suffering, whether physical or mental, is intentionally inflicted on a person for such purposes as obtaining from him or a third person information or a confession, punishing him for an act he or a third person has committed or is suspected of having committed, or intimidating or coercing him or a third person, or for any reason based on discrimination of any kind, when such pain or suffering is inflicted by or at the instigation of or with the consent or acquiescence of a public official or other person acting in an official capacity.

${ }^{137}$ Sørensen, above n 114, 101.

${ }^{138}$ Committee against Torture, Conclusions and Recommendations of the Committee against Torture: United States of America, $36^{\text {th }}$ sess, UN Doc CAT/C/USA/CO/2 (25 July 2006) [18]. For a similar finding that the enforced disappearance is a violation of the Convention against Torture, see Committee against Torture, Concluding Observations of the Committee against Torture: El Salvador, UN Doc CAT/C/SLV/CO/2 (9 December 2009) 4 and Committee against Torture, Concluding Observations of the Committee against Torture: Syrian Arab Republic, $44^{\text {th }}$ sess, UN Doc CAT/C/SYR/CO/1 (25 May 2010) 8.
} 
In its consideration of the initial report of Chad, the Committee against Torture went further and referred to enforced disappearance as a form of torture. It stated:

The Committee would welcome any statistics that the delegation could provide on disappearances, since it regarded any enforced disappearance as a form of torture, not only for the abducted person but also for his or her family. ${ }^{139}$

The UN Human Rights Committee has already given effect to the right not to be subjected to enforced disappearance. ${ }^{140}$

As an alternative to the multiplicity of treaty bodies that include the Committee on Enforced Disappearances, the proposal of a unified standing treaty body has been advanced. It is a proposal that fits well with the idea of a world court of human rights that is a unified body with enforcement powers. Alston summarises the reasons behind the proposal of a unified body as follows:

The following are among the advantages of a unified body suggested by the paper: it could adopt a holistic approach; its procedures could be more flexible and creative; its relative simplicity would facilitate the work of NGOs, national human rights institutions and other stakeholders; the interpretation of comparable provisions of different treaties would be consistent; General Comments would be consistent and clear; pending individual complaints would be adjudicated expeditiously, which would make the system more effective and attractive; follow-up capacity would be enhanced; it could be flexible in terms of the timing and venue of its sessions; it could take on supervision of new treaty standards if necessary; and it could work more closely with other human rights bodies, such as the special procedures or regional human rights bodies. Perhaps, most importantly, it "would inevitably be more visible than the existing treaty

\footnotetext{
${ }^{139}$ Committee against Torture, Summary Record of the First Part (Public) of the $870^{\text {th }}$ Meeting, $42^{\text {nd }}$ sess, UN Doc CAT/C/SR.870 (2009) 8 [49]. For the Concluding Observations on Chad, see Committee against Torture, Concluding Observations of the Committee against Torture: Chad, UN Doc CAT/C/TCD/CO/1 (4 June 2009).

${ }^{140}$ See, for example, Quinteros v Uruguay, UN Human Rights Committee, Communication No 107/1981, UN Doc CCPR/C/19/D/107/1981, (21 July 1983); and Sarma v Sri Lanka, UN Human Rights Committee, Communication No. 950/2000, UN Doc CCPR/C/78/D/950/2000, (31 July 2003).
} 
bodies, and would be able to make its procedures, recommendations and decisions better known at the national level. ${ }^{141}$

Still, there are those who subscribe to the idea of a system of multiple treaty bodies. For instance, Schöpp-Schilling suggests an 'innovative way of crossreferencing' to address the need for consistency in the conclusions of various treaty-bodies. ${ }^{142}$ O'Flaherty understands this 'cross-referencing' to mean the existence of multiple treaty bodies with greater harmonisation, coordination and integration than is taking place at present. ${ }^{143}$ The advantages of a unified treaty body are easy to appreciate. In the meantime, given the present realities of a schema of multiple treaty bodies, the Committee on Enforced Disappearances ought to take advantage of its unique position as a separate treaty body dealing exclusively with enforced disappearances. The Committee on Enforced Disappearances should make the most of the opportunity to focus its efforts on the complex issues of enforced disappearances and to devote its limited time and resources to the objectives of the Convention.

\section{Regional Bodies}

At the regional level, the work of the Committee on Enforced Disappearances potentially overlaps with the work of the Inter-American Court of Human Rights, the European Court of Human Rights and the African Commission on Human and Peoples' Rights. Unlike the Committee on Enforced Disappearances, the Inter-American Court and European Court, in applying the provisions of their respective conventions, are able to render binding decisions and award compensatory damages. ${ }^{144}$ More similar to the Committee on Enforced Disappearances in its lack of enforcement powers, the African Commission monitors compliance with the African Charter on Human and Peoples' Rights through its reporting procedure, individual communications procedure and inter-state communications procedure. ${ }^{145}$

141 Steiner, Alston and Goodman above n 13, 923 quoting Concept Paper on the High Commissioner's Proposal for a Unified Standing Treaty Body, UN Doc HRI/MC/2006/2 (22 March 2006).

${ }^{142}$ Hanna Beate Schöpp-Schilling, 'Treaty Body Reform: the Case of the Committee on the Elimination of Discrimination against Women' (2007) 7 Human Rights Law Review 201, $220-1$.

${ }^{143}$ O'Flaherty, above n 39, 325.

144 American Convention on Human Rights, opened for signature 22 November 1969, 1144 UNTS 123 (entered into force 18 July 1978) (American Convention), arts 62 and 63; and Convention for the Protection of Human Rights and Fundamental Freedoms, opened for signature 4 November 1950, 213 UNTS 221 (entered into force 3 September 1953) (European Convention), arts 32 and 41.

145 African Charter on Human and Peoples' Rights, adopted 27 June 1981, OAU Doc CAB/LEG/67/3/Rev. 5 (1981), reprinted in ILM 58 (1982) (entered into force 21 October 
These regional bodies are able to make their own contributions to the promotion of the right not to be subjected to enforced disappearance.

Since they are in a position to supplement what the Committee on Enforced Disappearances can do, these regional bodies 'illustrate the full range of the human rights movement's institutional architecture'. ${ }^{146}$ The Inter-American Court of Human Rights and the European Court of Human Rights have issued a range of relevant orders including the payment of compensation to the families of the disappeared. The binding decisions of these courts are indicative of the innovative institutions and processes possible at the regional level. $^{147}$

Contributing in their own way to raising the threshold of protection for victims of enforced disappearance, regional bodies enjoy a number of advantages in implementing rights. The UN General Assembly itself has affirmed the importance of regional bodies to promote and protect human rights since they 'are best placed to consider and resolve their own human rights situations, while upholding cultures, traditions and histories unique to the region' ${ }^{148}$ As summarised in a report, the advantages of regional bodies include:

(1) the existence of geographic, historical and cultural bonds among States of a particular region; (2) the fact that recommendations of a regional organization may meet with less resistance than those of a global body; (3) the likelihood that publicity about human rights will be wider and more effective; and (4) the fact that there is less possibility of 'general,

1986) (African Charter), part 2, chs 2 and 3. A protocol to the Charter establishes the African Court on Human and Peoples' Rights.

${ }^{146}$ Steiner, Alston and Goodman, above n 13, 925.

${ }^{147}$ See, for example, Velázquez Rodriguez v Honduras (29 July 1988) Inter-Am Ct H R (Ser C) No 4; Bamaca-Velásquez v Guatemala (2000) 70 Inter-Am.Ct.H.R. (ser C); Cyprus v Turkey, Application No. 25781/94, III European Court of Human Rights 1 (10 May 2001); and Dokayev v Russia, Application No. 16629/05, European Court of Human Rights, (9 April 2009).

148 Amanda Lloyd, 'A Theoretical Analysis of the Reality of Children's Rights in Africa: An Introduction to the African Charter on the Rights and Welfare of the Child' (2002) 2 African Human Rights Law Journal 11, 14, citing A S Wako, 'Towards an African Charter on the Rights of the Child' in The Rights of the Child. Selected Proceedings of a Workshop on the Draft Convention on the Rights of the Child: An African Perspective Nairobi (1989) 41, and F Viljoen, 'Supra-national Human Rights Instruments for the Protection of Children in Africa: The Convention on the Rights of the Child and the African Charter on the Rights and Welfare of the Child' (1998) 31 Comparative and International Law Journal of Southern Africa 199, 205. 
compromise formulae', which in global bodies are more likely to be based on considerations of a political nature. ${ }^{149}$

But not all regional mechanisms are as likely to promote the right not to be subjected to enforced disappearance. It remains to be seen how the revised Arab Charter of Human Rights establishing an Arab expert Human Rights Committee, the Charter of the Association of South East Asian Nations (ASEAN) committing members to the establishment of an ASEAN Human Rights Body and the attempts at a human rights mechanism for the Pacific will unfold. ${ }^{150}$ Nonetheless, the global and regional approaches to the promotion of the right not to be subjected to enforced disappearance can be 'both useful and complementary'.

\section{$3 \quad$ Working Group on Enforced or Involuntary Disappearances}

The mandate of the Committee on Enforced Disappearances may also need to be reconciled with the comparable mandate of the Working Group on Enforced or Involuntary Disappearances. The former UN Commission on Human Rights established this Working Group by Resolution 20 (XXXVI) of 9 February 1980. It has continued in existence under the UN Human Rights Council 'to examine questions relevant to enforced or involuntary disappearance'. ${ }^{152}$ Its five members serve as experts in their individual capacities. They consider reports of disappearances and can take immediate action by transmitting reports to governments and inviting them to respond. ${ }^{153}$ The duplication between this procedure and the urgent procedure of the Committee on Enforced Disappearances has already been noted in this article.

${ }^{149}$ Regional Promotion and Protection of Human Rights, $28^{\text {th }}$ Report of the Commission to Study the Organization of Peace (1980) 15, cited in Steiner, Alston and Goodman, above n 13,930 .

${ }^{150}$ See Andrea Durbach, Catherine Renshaw and Andrew Byrnes, 'A Tongue but No Teeth?: The Emergence of a Regional Human Rights Mechanism in the Asia Pacific Region' (2009) 31 Sydney Law Review 211; and Vitit Muntarborn, 'Human Rights Monitoring in the AsiaPacific Region' in Alfredsson, above n 8, 641.

151 'Regional Promotion and Protection of Human Rights, $28^{\text {th }}$ Report of the Commission to Study the Organization of Peace' (1980) 15, cited in Steiner, Alston and Goodman above n 13,930 .

152 Commission on Human Rights, Resolution 20 (XXXVI), $1563^{\text {rd }}$ meeting on 29 February 1980, UN Doc E/CN.4/2004/59 (2004), Annex IV.

153 For a general discussion on the UN Working Group on Enforced or Involuntary Disappearances, see Rodley above n 79, 705-11. 
Like the Committee on Enforced Disappearances, the office of the Working Group has the mandate of assisting families in determining the fate of disappeared relatives by establishing a channel of communication between the families and the governments concerned. It continues working on a disappearance case until the fate of the disappeared relative is clarified. ${ }^{154}$

But the work of the Committee on Enforced Disappearances does not necessarily conflict with that of the Working Group on Enforced or Involuntary Disappearances. As Switzerland, Argentina, Belgium, Canada, Chile, Costa Rica, Ireland, Italy, Mexico and Spain stated at the fifth drafting session, the entry into force of the Convention is without prejudice to the mandate of the Working Group on Enforced or Involuntary Disappearances, which continues to operate within the framework of its own universal mandate. ${ }^{155}$

To borrow the terminology used during the third and fourth drafting sessions, the relationship between the Committee and the Working Group on Enforced and Involuntary Disappearances is one of 'complementarity'. The mandate of the Working Group covers all members of the UN and all disappearances since the founding of the UN while the Committee's mandate is limited to parties to the Convention and disappearances after its entry into force. Experience in other areas such as torture has demonstrated the usefulness of having different bodies working on the same theme. ${ }^{156}$

In their own way, these other international and regional bodies have begun to address the harms experienced by families of the disappeared. It is on what they have achieved that the Committee may need to build, if it is to make its own distinctive contribution. These other bodies will carry on with their work after the Committee's establishment. The Committee will establish close cooperation with them in accordance with article 28, paragraph 1 of the Convention. ${ }^{157}$

\footnotetext{
${ }^{154}$ Scovazzi and Citroni, above n 85, 247.

${ }^{155}$ Commission on Human Rights, Report of the Intersessional Open-ended Working Group to Elaborate a Draft Legally Binding Normative Instrument for the Protection of All Persons from Enforced Disappearance, 62 ${ }^{\mathrm{nd}}$ sess, UN Doc E/CN.4/2006/57 (2 February 2006) 51.

${ }^{156}$ Commission on Human Rights, Report of the Intersessional Open-ended Working Group to Elaborate a Draft Legally Binding Normative Instrument for the Protection of All Persons from Enforced Disappearance, $61^{\text {th }}$ sess, UN Doc E/CN.4/2005/66 (10 March 2005) 35.

${ }^{157}$ Article 28(1) states: 'In the framework of the competencies granted by this Convention, the Committee shall cooperate with all relevant organs, offices and specialized agencies and funds of the United Nations, with the treaty bodies instituted by international instruments, with the special procedures of the United Nations and with the relevant regional
} 


\section{Competence Ratione Temporis}

A cause for some concern is article 35 of the Disappearances Convention, which limits the competence of the Committee to enforced disappearances which 'commenced' after the entry into force of the Convention. If a state becomes a party to this Convention after its entry into force, the obligations of that state vis-à-vis the Committee relates only to enforced disappearances 'commencing' after the entry into force of this Convention for the state concerned.

I question the soundness of this limitation on the competence of the Committee. Other human rights treaties impose a lesser limitation. The Rome Statute, according to which enforced disappearances are a crime against humanity, provides that the International Criminal Court has jurisdiction 'only with respect to crimes committed after the entry into force' of the Statute. ${ }^{158}$ The use of the word 'committed' in the Rome Statute instead of the word 'commenced' in the Disappearances Convention leaves open the possibility of an exercise of jurisdiction over acts that 'commenced' before entry into force for as long as they continue to be 'committed' after entry into force.

In imposing a lesser limitation than the Disappearances Convention, the Optional Protocol to the Convention on the Rights of Persons with Disabilities is even more explicit. Article 2(f) of this protocol considers individual communications inadmissible if: "The facts that are the subject of the communication occurred prior to the entry into force of the present Protocol for the State Party concerned unless those facts continued after that date'. This protocol makes possible the exercise of competence over acts that started before entry into force for as long as they continued afterwards.

The limitation on the competence of the Committee to act in matters of enforced disappearances which 'commenced' after the entry into force of the Convention disregards the nature of the enforced disappearance as a continuing violation. The UN Declaration on the Protection of All Persons from Enforced Disappearance provides that enforced disappearances 'shall be considered a continuing offence as long as the perpetrators continue to conceal the fate and whereabouts of persons who have disappeared and these

\footnotetext{
intergovernmental organizations or bodies, as well as with all relevant State institutions, agencies or offices working towards the protection of all persons against enforced disappearances.'

${ }^{158}$ Rome Statute of the International Criminal Court 1998, opened for signature 17 July 1998 , 2187 UNTS 3 (entered into force 1 July 2002) art 11(1).
} 
facts remain unclarified'. ${ }^{159}$ Similarly, the Inter-American Convention on the Forced Disappearance of Persons states that the offence of forced disappearance 'shall be deemed continuous or permanent as long as the fate or whereabouts of the victim has not been determined'. ${ }^{160}$ The Working Group on Enforced or Involuntary Disappearances has stated in relation to the enforced disappearance that it is a 'continuing offence as long as the perpetrators continue to conceal the fate and the whereabouts of persons who have disappeared and these facts remain unclarified'. ${ }^{161}$ Article 8 of the Disappearances Convention itself acknowledges this continuous nature in relation to term limitations.

The fact that the treaty violation caused by the enforced disappearance continues for as long as the whereabouts of the disappeared person are unknown, is recognised in the jurisprudence of the UN Human Rights Committee. According to the Committee in Sarma v Sri Lanka, although the victim's alleged removal and subsequent disappearance took place before the entry into force of the Optional Protocol to the ICCPR for the state concerned, the violations of the ICCPR, if confirmed on the merits, might have occurred or continued after the entry into force of the Optional Protocol. ${ }^{162}$ For its part, in Velázquez Rodriguez $v$ Honduras, the InterAmerican Court found an enforced disappearance to be a continuous violation of many rights under the American Convention. ${ }^{163}$ In Varnava v Turkey, the European Court of Human Rights has also had occasion to give recognition to this continuing nature. Rejecting an objection grounded on a lack of temporal jurisdiction, ${ }^{164}$ it has held that, since an enforced disappearance is 'drawn out over time, prolonging the torment of the victim's relatives', the 'ongoing

159 United Nations General Assembly, Declaration on the Protection of All Persons from Enforced Disappearance, A/RES/47/133 (18/12/1992) art 17.

${ }^{160}$ Inter-American Convention on the Forced Disappearance of Persons, opened for signature 9 June 1994, 33 ILM 1529 (entered into force 28 March 1996) art 3.

${ }^{161}$ Working Group on Enforced or Involuntary Disappearance, General Comment on Article 17 of the Declaration, UN Doc E/CN.4/2001/68 (2000), [26].

162 Sarma v Sri Lanka, UN Human Rights Committee, Comm. No. 950/2000, UN Doc CCPR/C/78/D/950/2000, 31 July 2003, para 6.2. But see Cifuentes Elgueta v Chile, UN Human Rights Committee, Comm. No. 1536/2006, UN Doc CPR/C/96/D/1536/2006, 7 September 2009, para 8.5; Acuña Inostroza et al. v. Chile, UN Human Rights Committee, Comm. No. 717/1996, UN Doc CCPR/C/66/D/717/1996, 23 July 1999, para 6.4; and Yurich v. Chile, UN Human Rights Committee, Comm. No. 1078/2002, UN Doc CCPR/C/85/D/1078/2002, 2 November 2005, para. 6.4.

${ }^{163}$ Velázquez Rodriguez v Honduras (29 July 1988) Inter-Am Ct HR (ser C) No 4, [191].

164 The disappearance commenced before the European Convention entered into force with respect to the state party concerned. 
failure to provide the requisite investigation will be regarded as a continuing violation'. ${ }^{165}$

There is further support for this continuing nature of the enforced disappearance in the jurisprudence of other courts. In Selimovic v Republika Srpska, the Human Rights Chamber for Bosnia and Herzegovina found the applications admissible even if the events in question had taken place before the entry into force of the Dayton Peace Agreement. Considering that, seven years after the events, none of the applicants had been officially informed about the fate and whereabouts of their missing relatives, the Chamber held that allegations contained in the applications concerned a continuing violation of the applicants' human rights. ${ }^{166}$ The Supreme Court of Chile has cited the continuing nature of the offence of enforced disappearance as one of its grounds for denying the application of an amnesty law and a statute of limitation to those responsible for an enforced disappearance. ${ }^{167}$

For as long as the truth about a disappearance is unknown - even if it started before the entry into force of the Convention - the Committee ought to be competent to consider it. Such consideration would not constitute retrospective application of the Convention since the violation is ongoing and remains current. As the delegations of Argentina, Chile and Italy asserted during the drafting sessions, they intend to make an interpretative declaration when ratifying the Convention extending the application of certain obligations to enforced disappearances commencing even before entry into force for as long as the fate of the disappeared person is not clarified. ${ }^{168}$

\section{D $\quad$ Limited Time and Resources}

Another problem is that there will be constraints on the time and resources available to the Committee on Enforced Disappearances. Quashigah establishes a link between budgetary constraints and how effective a treaty

165 Varnava v Turkey (2009), Application Nos. 16064/90, 16065/90, 16066/90, 16068/90, 16069/90, 16070/90, 16071/90, 16072/90 and 16073/90, Eur HR 18 September 2009, [148].

${ }^{166}$ Selimovic v Republika Srspka, Case no CH/01/8365, Human Rights Chamber for Bosnia and Herzegovina, 7 March 2003 [169].

167 Juan Contreras Sepúlveda y otros (crimen) casación fondo y forma, Corte Suprema, 517/2004, Resolución 22267 cited in Fanny Lafontaine, 'No Amnesty or Statute of Limitation for Enforced Disappearances' (2005) 3 Journal of International Criminal Justice 469, 471.

${ }^{168}$ Commission on Human Rights, $62^{\text {nd }}$ sess, Report of the intersessional open-ended working group to elaborate a draft legally binding normative instrument for the protection of all persons from enforced disappearance, UN Doc E/CN.4/2006/57 (2006) 15. Argentina and Chile have ratified the Convention, but not Italy as yet. Neither Argentina nor Chile entered this interpretation as a reservation. 
body can be. ${ }^{169}$ Steiner, Alston and Goodman use the following words in relation to the UN Human Rights Committee, a body that is subject to similar limitations:

The Committee meets for three sessions annually, each three weeks long, at the UN Office in Geneva (twice) and at the UN headquarters in New York. There is some intersessional work by individual members in the context of Working Groups, which meet for one week prior to the start of each session. Living and travel expenses are paid by the UN but since 2002 an annual honorarium of $\$ 3,000$ previously paid to members had been reduced to a token of $\$ 1$, in order to save money. The work is part-time, members hold 'regular,' often full-time, jobs, and must fit the Committee's work into already busy schedules. ${ }^{170}$

But the experience of other treaty bodies gives the Committee on Enforced reason for hope. In so far as the UN Human Rights Committee is concerned, in spite of time and resource constraints, it 'has assumed the character, structure and functions that it has' ${ }^{171}$ Given its more specific mandate, the workload of the Committee on Enforced Disappearances will likely be lighter than that of the UN Human Rights Committee. Still, to some extent, the Committee on Enforced Disappearances will be subject to similar limitations and will need to transcend them if it is to make its own contribution to fostering greater respect for the right not to be subjected to enforced disappearance.

By way of summary, there are several limitations to which the Committee is subject. Issues of duplication, lack of enforcement powers, competence ratione temporis and time and resource constraints set the parameters of what the Committee can do. The challenge is for the Committee to work within these parameters and make the most out of its role in order to make a meaningful contribution to international human rights.

\section{CONCLUSION}

The efficacy of any human rights instrument depends in part on the mandate of the body charged with monitoring its implementation by states parties. ${ }^{172}$

\footnotetext{
${ }^{169}$ Kofi Quashigah, 'The African Charter on Human and Peoples' Rights: Towards a More Effective Reporting Mechanism' (2002) 2 African Human Rights Law Journal 261, 279-80.

${ }^{170}$ Steiner, Alston and Goodman, above n 13, 847.

${ }^{171}$ Ibid 844

${ }^{172}$ Wilder Tyler, 'Background on the Elaboration of the Draft International Convention for the Protection of All persons from Forced Disappearance' in Review of the International
} 
With its Convention-given mandate, the Committee on Enforced Disappearances has considerable potential to make a distinctive contribution to the strengthening of the right not to be subjected to enforced disappearance. Its reporting, individual communications and inter-state communications procedures have enhanced features that build on the experiences of other monitoring bodies with similar procedures. The Committee also introduces a number of innovations. Its urgent, visit and referral procedures contain novel elements that can promote compliance with the right not to be subjected to enforced disappearance. The urgent procedure, which is unprecedented in a human rights treaty, seeks not only to forestall enforced disappearances, but also to put an end to those that have already occurred. The visit procedure has the potential to develop into an important fact-finding tool. The referral procedure enables well founded indications of the practice of enforced disappearance on a widespread or systematic scale to reach the attention of the UN General Assembly through the Secretary-General. As Steiner, Alston and Goodman observe, recent treaties such as the Disappearances Convention are 'more creative in terms of monitoring arrangements' than previous treaties have been. ${ }^{173}$

The establishment of the Committee as a new body to supervise the implementation of the Convention better promotes the objectives of the Convention than the assignment of new functions to an existing body. A separate international treaty-monitoring body able to devote itself exclusively to the question of enforced disappearances makes possible a more in-depth study of this complex right and enables the development of expertise in this area.

Mindful of time and resource constraints, those who created the new international treaty body also made possible swifter action, something that can be crucial to saving the lives of disappeared persons. Time is of the essence when the right not to be subjected to enforced disappearance is invoked. A separate treaty body is better equipped to deal with the exigencies of the situation. As Pourgourides points out:

As regards the need for a rapid intervention mechanism, experience has shown that the time factor is crucial. When perpetrators of enforced disappearances are faced with rapid reactions from the family, local community, or central authorities, sometimes prompted to intervene by international bodies, and ideally as long as the 'chain of known custody' is

Commission of Jurists, special issue on Impunity, Crimes against Humanity and Forced Disappearance (2001) 63, 71-2 cited in Scovazzi and Citroni, above n 85, 387.

${ }^{173}$ Steiner, Alston and Goodman, above n 13, 919. 
not yet interrupted, lives can be saved. Some disappeared persons reappear after the perpetrators have realised, or have been made to understand that the price - in terms of risk of prosecution or loss of respectability - to be paid for definitely 'disappearing' the victim is too high. But the existing mechanisms are too weak, and in particular, too slow, in order to achieve success. A new international instrument on enforced disappearances should therefore foresee such a mechanism, perhaps along the lines of that foreseen in the first draft of the Inter-American Convention. ${ }^{174}$

As part of a system of international and regional bodies, each one contributing in its own way to fostering greater respect for the right not to be subjected to enforced disappearance, the Committee is a welcome addition to the international machinery for raising awareness of the right and discouraging violations.

With its potential to induce respect for human rights and to help move states toward the goal of preventing enforced disappearance, the Committee can help avoid the 'paradox of empty promises' that Hafner-Burton and Tsutsui warn us about. ${ }^{175}$ Just as the Convention contributes to the growing legitimacy of the right not to be subjected to enforced disappearance, so too the Committee can better perform its monitoring functions in a manner that induces governments to respect this right. Within the limits of its mandate and with the active involvement of NGOs and civil society, ${ }^{176}$ the Committee can play a significant role in determining, both substantively and procedurally, the future successof the Convention's guarantee. It will be up to the Committee to transform the Convention into an instrument of change and to help ensure that its promise of the right not to be subjected to enforced disappearance becomes a reality.

\footnotetext{
174 Council of Europe, Parliamentary Assembly, Enforced Disappearances, Report to the Committee on Legal Affairs and Human Rights, Rapporteur Mr Christos Pourgourides, Doc 10679 (19 September 2005) [61], cited in Scovazzi and Citroni, above n 85, 391.

${ }^{175}$ Emilie M Hafner-Burton and Kiyoteru Tsutsui, 'Human Rights in a Globalizing World: The Paradox of Empty Promises' (2005) 110(5) American Journal of Sociology 1373.

${ }^{176}$ High Commissioner for Human Rights, Navi Pillay asserts that the involvement of NGOs and civil society 'is indispensible to produce concrete results on the ground where it matters the most.' Navi Pillay, High Commissioner: Crucial Role of Civil Society in the Implementation of Anti-racism Conference Outcome (April 2009) Office of the High Commissioner for Human Rights <http://www.ohchr.org/EN/NewsEvents/Pages/DRCRole CivilSociety.aspx $>$.
} 